\title{
AMOR E LIBERDADE EM HEIDEGGER
}

\author{
Acylene Maria Cabral Ferreira* \\ acylene@ufba.br
}

Wem sonst als Dir.

A quem senão a ti.

Hölderlin

RESUMO Nosso objetivo é mostrar, a partir das obras Ser e tempo e Seminários de Zollikon, a constituição ontológica do amor como a afinação (Stimmung) fundamental para a convivência da presença (Dasein). Nossa hipótese sustenta-se no pressuposto que a copertença do amor (abertura fundamental para o outro) e da liberdade (deixar-ser o outro) consiste em uma modificação do existencial da disposição e expressa a unidade e a circularidade ontológica do ser-no-mundo. Pretendemos mostrar ainda que a solicitude (a abertura do ser-com) é a condição de possibilidade para a constituição ontológico-existencial da afinação do amor. Centrados no texto Sobre a essência da verdade, nosso intuito é sublinhar que a liberdade é também uma modificação do existencial da disposição, ou seja, uma afinação, e enquanto tal é o fundamento ontológico para o desvelamento do modo próprio (eigentliche) de ser da presença. Nesta perspectiva, podemos afirmar que a afinação da liberdade precede e penetra a afinação do amor. Isto significa que a afinação do amor se funda na afinação da liberdade e que esta ressoa naquela, o que nos permite dizer que elas são co-originárias.

Palavras-chave Amor, liberdade, afinação, solicitude, ser-com, disposição.

* Professora do Departamento de Filosofia da UFBA. Artigo recebido em 4/03/2010 e aprovado em $14 / 01 / 2011$.

KRITERION, Belo Horizonte, nº 123, Jun./2011, p. 139-158. 
ABSTRACT The objective of the present paper is to show, using Being and Time and Zollikon Seminars, the existential-ontological constitution of love as a mood (Stimmung) fundamental to the coexistence of Dasein. The hypothesis advanced here is that the co-pertinence of love (the fundamental disclosedness to the other) and of freedom (the letting-be of the other) consists in a modification of the existential of state-of-mind and expresses the unity and ontological circularity of Being-in-the-world. We intend also to show that solicitude (the disclosedness towards Being-with) is the condition of possibility for the existential-ontological constitution of the mood of love. Centered on the text On the Essence of Truth, our purpose is to emphasize that freedom is also a modification of the existential of state-of-mind or, one might say, mood, and as such it is the ontological ground for uncovering a proper (eigentliche) way of Being. In this way, we are able to affirm that the mood of freedom precedes and penetrates the mood of love. This means that the mood of love is founded in the mood of freedom and that it resonates in that mood, which permits us to say that they are co-originating.

Keywords Love, freedom, mood, solicitude, being-with, state-of-mind.

\section{Introdução}

Heidegger é criticado pelo seu silêncio em relação ao amor. Em Ser e tempo, sua obra mais divulgada, encontramos apenas uma referência sobre o amor através de uma nota que contém citações de Pascal e de Santo Agostinho. ${ }^{1}$ Depois desta obra temos alguma discussão sobre o amor em Nietzsche I e nos Seminários de Zollikon. "Graças a publicação das últimas lições de Marburgo do semestre de verão de 1928, sabemos que a referência ao papel fundamental do amor provém das conversas com Max Scheler sobre o problema da intencionalidade." 2 No entanto, a pouca dedicação ao tema do amor não implica em que Heidegger desconsiderava a importância deste para a filosofia. Esta observação nos parece suficiente e justificável para nos ocuparmos com a questão do amor. Antes, faz-se necessário ressaltar que, em 1987, Giorgio Agamben proferiu, em Paris, uma conferência intitulada La passion de la facticité; nela ele afirmou que o amor é uma paixão da

1 Cf. HEIDEGGER, Martin. Ser e tempo. Petrópolis: Vozes, 2006; p. 198.

2 AGAMBEN, Giorgio; PIAZZA,Valeria. La passion de la facticité. In: L'ombre de l'amour: le concept d'amour chez Heidegger. Paris: Payot \& Rivages, 2003; p. 11. 
facticidade do Dasein (presença) ${ }^{3}$, através da qual a presença experimenta a liberdade como impotência. Do nosso ponto de vista, o amor concerne mais propriamente a estrutura ser-no-mundo, visto que esta modalidade estrutural pressupõe a abertura da presença para os demais entes que compartilham o mundo com ela. "Deste modo, é fundamentando-nos na analítica existencial, e não procurando 'completa-la', que podemos elaborar uma 'fenomenologia do amor'." Podemos acrescentar, em consonância com Agamben, que os temas do amor e da liberdade encontram-se subentendidos aos existenciais que estruturam e constituem as aberturas da presença em sua relação com o ser e com os demais entes. Considerando-se que amor e liberdade se fundamentam nas estruturas existenciais da presença podemos, neste primeiro momento, afirmar que a liberdade e o amor são aberturas ontológico-existenciais do serno-mundo. Esta nossa afirmação, que inicialmente pode parecer precipitada e leviana, sustenta-se em uma passagem dos Seminários de Zollikon, segundo a qual o amor se funda na compreensão de ser. ${ }^{5}$ Sendo assim podemos dizer, com segurança, que o amor se fundamenta em um existencial. Qual o aporte teórico que assegura tal inferência? A existencialidade da presença, que consiste na copertinência dos existenciais e das aberturas igualmente originárias que determinam, a cada vez e genuinamente, os modos de ser da presença. De acordo com o parágrafo 31 de Ser e Tempo o existencial do compreender se afina com o existencial da disposição e este possui sempre a sua compreensão de ser. ${ }^{6}$ Estas referências teóricas específicas que fizemos dos Seminários de Zollikon e de Ser e Tempo nos permitem correlacionar o amor ao existencial da disposição e, consequentemente, defini-lo como uma afinação (Stimmung). ${ }^{7}$ Pois, "o que indicamos ontologicamente com o termo disposição é, onticamente, o mais conhecido e o mais cotidiano, a saber, o humor, o estar afinado num humor."

$\mathrm{Na}$ conferência supracitada Giorgio Agamben afirma que o amor é uma Stimmung ausente em Ser e tempo. Esta afirmação é importantíssima e decisiva para nossa reflexão sobre o amor em Heidegger, porque ela nos apóia e nos autoriza a defendermos a tese de que o amor é um modo de afinação.

3 Usaremos a palavra "presença" para traduzir a palavra "Dasein", conforme a tradução brasileira de Ser e Tempo.

4 DASTUR, Françoise. Binswanger lecteur de Être et temps: Amour, nostrité et souci. In: CABESTAN, Philippe; DASTUR, Françoise; Ecole Française de Daseinanalyse (org.). Lectures d'Être et temps de Martin Heidegger: Quatre-vingts ans après. Argenteuil: Le Cercle Herméneutique, 2008; p. 119.

5 Cf. HEIDEGGER, Martin. Seminários de Zollikon. Petrópolis: Vozes, 2001; p. 206.

6 Cf. Idem. Ser e Tempo; p. 202.

7 Stimmung é uma palavra alemã traduzida para o português como afinação, humor e tonalidade afetiva. Optamos pelo uso da palavra "afinação".

8 HEIDEGGER, Martin. Ser e Tempo; p. 193. 
"Se Heidegger, mesmo reconhecendo a ordem fundamental do amor, não trata tematicamente deste problema, é precisamente porque o modo de ser da abertura mais original do que todo conhecimento (este que segundo Agostinho e Scheler tem lugar no amor) é, em certo sentido, o problema central de Ser e tempo." ${ }^{\prime 9}$ A abertura mais original a que Agamben se refere é a estrutura ser-nomundo, pois ela fundamenta a presença como um ente que sendo já se encontra aberto e lançado junto ao mundo. Esta característica da presença Heidegger denomina de facticidade: "o caráter de fatualidade do fato da presença em que, como tal, cada presença é." 10 Cabe sublinhar que a facticidade da presença expõe um duplo caráter de factualidade: de que a presença seja, de que ela esteja lançada no mundo neste ou naquele modo de ser. Este duplo caráter da facticidade é a condição de possibilidade para a constituição do caráter de abertura da presença. Sendo facticidade, a estrutura ser-no-mundo é a abertura mais original da presença, por isto esta estrutura será a base para a nossa reflexão sobre o amor e liberdade em Heidegger.

Apesar de concordarmos com Agamben que amor e liberdade são copertencentes na filosofia heideggeriana, seguimos uma trajetória de exposição do tema bastante diversa desta que ele apresentou em La passion de la facticité, especialmente, a referência ao amor como uma paixão da facticidade $^{11}$ e a liberdade como uma experiência de impotência ${ }^{12}$. O fato de considerarmos o amor como uma afinação, em vez de uma paixão, exige uma elaboração do conceito de amor completamente diferente desta de Agamben. Por quê? Enquanto paixão da facticidade, o amor se fundamenta no existencial da decadência, enquanto afinação ele se fundamenta no existencial da disposição. Isto porque, em Ser e tempo, a facticidade é o caráter do existencial da decadência e a afinação é uma modificação do existencial da disposição. Por que deslocamos a fundamentação do amor para o existencial da disposição? Por um motivo muito simples: qualquer modalidade de amor implica em uma sintonia ou uma afinação da presença com a co-presença. Qual é a consequência oriunda deste deslocamento? A facticidade deixa de ser o pilar que suporta e estrutura o conceito de amor em Heidegger. Assim, em vez de relacionarmos a facticidade às noções de impotência radical ${ }^{13}$, irredutível

9 AGAMBEN, Giorgio; PIAZZA,Valeria. La passion de la facticité. In: L'ombre de l'amour: le concept d'amour chez Heidegger; p. 14.

10 HEIDEGGER, Martin. Ser e Tempo; p. 102.

11 AGAMBEN, Giorgio; PIAZZA,Valeria. La passion de la facticité. In: L'ombre de l'amour: le concept d'amour chez Heidegger; p. 51.

12 Ibidem; p. 46.

13 Ibidem; p. 43. 
impropriedade ${ }^{14}$, eternidade e além do $\operatorname{ser}^{15}$, entendemos que a facticidade é o fundamento para o desvelamento do modo próprio de ser da presença. Como? $\mathrm{Na}$ decadência a presença fática está no modo de ser da impropriedade, ou seja, ela se desvela no modo de ser dos outros. Sendo assim, a dissimulação de si nos outros é o modo de desvelamento da presença. Isto significa que o modo próprio de ser da presença encontra-se latente em seu modo impróprio de ser. Quer dizer, velamento e desvelamento formam uma duplicidade inerente ao existencial da decadência. Esta duplicidade é a condição de possibilidade que consente a presença fática a dissuadir-se da latência e a desvelar-se propriamente. Porque a decadência, existencialmente, se expressa como facticidade, podemos acrescentar que a duplicidade velamento/desvelamento se expressa na facticidade como a duplicidade propriedade/impropriedade. Qual a função destas duplicidades? Elas nos permitem inferir que a facticidade, mediante o seu caráter de impropriedade, é a condição de possibilidade para o desvelamento do modo próprio de ser da presença. Embora a facticidade se caracterize pela impropriedade não pensamos, como Agamben, que ela seja eterna e além do ser, já que vez por outra a presença fática cai na propriedade. Para ele, o dinamismo e reciprocidade entre propriedade e impropriedade tem o seu fim no amor, pois "os amantes suportam até o extremo a impropriedade do amor afim de que o próprio possa surgir como apropriação desta livre impotência que a paixão leva a seu extremo." ${ }^{16}$ Ora, se desta apropriação da impotência surge o próprio, então, o amor não seria a apropriação do próprio na impropriedade? Isto não diz o mesmo que o amor concerne ao próprio? Neste caso, em vez de pensarmos o amor como uma impotência da liberdade que nos mantém na irredutível impropriedade, refletiremos em que medida o amor é a abertura que libera a presença e a co-presença para seu modo próprio de ser. Nesta perspectiva, defendemos que a copertença de amor e liberdade consiste em que a afinação da liberdade, enquanto deixar-ser o ente, funda a afinação do amor como a afinação fundamental para a convivência da presença em sua cotidianidade.

Em Ser e Tempo, a angústia é definida como a disposição fundamental e em Conceitos fundamentais de metafisica: mundo, finitude, solidão, o tédio profundo é visto como humor, afinação ou tonalidade afetiva fundamental para filosofar. Para Heidegger "toda e qualquer tonalidade afetiva fundamental (Grundstimmung) autêntica libera e aprofunda, ata e desata as 
outras. [...] Portanto, é igualmente equivocado absolutizar uma tonalidade afetiva fundamental como a única e relativizar todas as tonalidades afetivas fundamentais em relação às outras." $17 \mathrm{O}$ mérito desta citação está em que ela tanto nos certifica que o tédio profundo não é a única tonalidade afetiva ou afinação fundamental sob a qual todas as outras estariam subjugadas, quanto acentua a copertença e co-originariedade entre as afinações fundamentais. Esta constatação nos capacita e habilita a dispormos do amor como a afinação fundamental para a convivência da presença.

Entretanto, é oportuno perguntar-nos: como será possível tratarmos do tema do amor com consistência e legitimidade, visto que Heidegger quase não se ocupou dele? Pretendemos enfrentar o desafio de avançar no pensamento heideggeriano refletindo sobre o amor, através da análise dos conceitos de sercom e solicitude ${ }^{18}$ descritos em Ser e tempo e do conceito de liberdade como "disposição afetiva e deixar-ser o ente" descrito no texto Sobre a essência da verdade. Nossa confiança neste percurso teórico advém das seguintes palavras de Günter Figal: "podemos recorrer à riqueza descritiva de $S T$ e desenvolver o pensamento central do filosofar heideggeriano, na medida em que investigamos as descrições de $S T$ e em parte também as levamos além."19 Para mostrarmos a consistência de nossa hipótese, qual seja, que a copertença do amor, como abertura para o outro, e da liberdade, como deixar-ser o outro, constitui a afinação fundamental para a convivência da presença, transcrevemos a citação dos Seminários de Zollikon que nos remete ao instrumental teórico de Ser e tempo: "o cuidado (Sorge/Cura)20, compreendido corretamente, isto é, como modo ontológico-fundamental, nunca pode ser diferenciado do 'amor', mas sim, ele é o nome da constituição ek-stático-temporal do traço fundamental do Dasein, a saber, como compreensão de ser." ${ }^{21}$ De acordo com a filosofia heideggeriana podemos acrescentar que a similaridade da constituição ontológico-existencial entre amor, cura e compreensão de ser concentra-se na abertura da presença para o ser e para o outro, isto é, concerne a abertura mais original da presença: ser-no-mundo. Por esta razão, a copertinência das

17 HEIDEGGER, Martin. Conceitos fundamentais de metafísica: mundo, finitude, solidão. Rio de Janeiro: Forense, 2003; p. 211.

18 Tradução francesa de Martineau para o termo "Fürsorge". A tradução brasileira para este termo é preocupação.

19 FIGAL, Günter. Martin Heidegger: fenomenologia da liberdade. Rio de Janeiro: Forense, 2005; p. 21.

20 Geralmente a palavra Sorge é traduzida como cuidado. Entretanto a versão brasileira de Ser e tempo, para guardar as diferenças das dimensões ontológicas e ônticas, conservou o termo latino "cura" para Sorge, referindo-se a constituição ontológica da presença, e o termo "cuidado" para a dimensão ôntica, ou seja, para referir-se as realizações concretas da presença (cf. Ser e tempo, notas 12 e 13; p. 564-5).

21 HEIDEGGER, Martin. Seminários de Zollikon; p. 206. 
aberturas do ser-no-mundo constituirá o eixo propulsor para pensarmos a questão do amor e liberdade em Heidegger.

Em seus estudos sobre o amor fati e a vontade de poder como afeto, paixão e sentimento Heidegger recupera o pensamento nietzschiano, no qual “todos os afetos são 'configurações' da vontade de poder. Se perguntarmos o que é a vontade de poder, Nietzsche então responderá: ela é o afeto originário. Os afetos são formas da vontade; a vontade é afeto." ${ }^{.2}$ Apesar dos temas da paixão, da vontade, do querer e do desejar serem comuns as discussões sobre o amor, não trataremos deles aqui, porque em Ser e tempo a possibilidade ontológica do querer está correlacionada aos momentos constitutivos da cura e o "desejar pressupõe a cura." 23 Portanto, querer e desejar são fenômenos da presença enquanto cura e o amor, sob nosso olhar, é um fenômeno da presença enquanto disposição. Metodologicamente os momentos estruturais e constitutivos da presença na analítica existencial são tratados separadamente, mas existencialmente e faticamente eles expressam a unidade e a circularidade ontológica do ser-no-mundo. $\mathrm{Na}$ analítica existencial, o fenômeno da cura responde pela unidade e totalidade do todo estrutural da presença, consequentemente a disposição, o ser-com e a afinação do amor concernem à cura. Assim, do ponto de vista ontológico querer, desejo, amor, disposição, ser-no-mundo, ser-com, cura etc. são tratados de formas distintas, porém existencialmente respondem pela unidade dos modos de ser da presença. Por isto do ponto de vista ôntico querer, amor e desejo também são vistos sob perspectivas diferentes, mas faticamente encontram-se intimamente entrelaçados e expressam a profusão e a correlação dos modos de ser da presença cotidiana. Porque em nosso entendimento a circularidade ontológica fundamenta a constituição da estrutura ser-no-mundo e das aberturas da presença, consideramos que ela é a condição de possibilidade necessária para refletirmos sobre o amor e liberdade em Heidegger. Nosso objetivo consiste em mostrar que o nexo ontológico das duplicidades da facticidade, ser-com, solicitude e das duplicidades das afinações do amor, solidão e liberdade espelha e reflete a circularidade ontológica, que estrutura a totalidade e a unidade dos diferentes modos de ser da presença em sua cotidianidade. 


\section{A circularidade ontológica do ser-com e o amor como afinação}

Conforme Heidegger "a 'doutrina' de um pensador é isto que, em suas palavras, permanece informulado, mas que está aberto ao homem, 'exposto', afim de que ele possa gasta-la sem contar. Se queremos apreender e conhecer doravante isto que um pensador não disse, qualquer que seja a natureza, nos é necessário considerar isto que ele disse." ${ }^{24}$ Dessa forma, se queremos apreender o não dito no pensamento de Heidegger sobre o amor: a Stimmung ausente, devemos partir dos conceitos que ele elaborou. Como anteriormente anunciamos seria impossível tratarmos de afinação do amor sem antes explicitarmos como se constitui a estrutura ser-no-mundo, já que ela é o fundamento ontológico-existencial da presença em sua relação com o mundo. Em que sentido esta estrutura nos ajuda a refletir sobre o amor no pensamento heideggeriano? Por que através dela podemos pensar o amor como afinação? Por que sua abertura é essencial para a afinação do amor? Como ela se constitui?

A estrutura ser-no-mundo é constituída pela unidade dos existenciais do ser-em, ser-junto e ser-com. Estes existenciais são igualmente primários e originários mas inseparáveis no que diz respeito a determinação da presença como ser-no-mundo. Enquanto ser-em a presença é e está lançada no mundo, enquanto ser-junto ela toca e é tocada pelo mundo e enquanto ser-com ela encontra-se em uma relação de solicitude com a outra presença. Sendo existenciais cada um deles apresenta com igual originariedade e inseparabilidade um caráter de abertura. Assim como o existencial da disposição se fundamenta neste do compreender e reciprocamente, o existencial do serjunto se funda neste do ser-em e o existencial do ser-com se fundamenta neste do ser-em e ser-junto e reciprocamente. Como recurso metodológico, indicaremos em separado a abertura pertinente aos existenciais que estruturam a presença enquanto ser-no-mundo: [i] "Essa abertura prévia do mundo, que pertence ao ser-em, também se constitui de disposição." ${ }^{25}$ [ii] A abertura do ser-junto condiz com a abertura da significância da mundanidade do mundo. [iii] Já a abertura que diz respeito ao existencial do ser-com é a abertura para o outro, a solicitude. Dada a constituição ontológico-existencial da estrutura ser-no-mundo, perguntamos: qual é o fundamento desta estrutura mais original da presença? "A afecção (disposição) é a condição de possibilidade de um 'dirigir-se para' (Sichrichten auf). (Portanto) onde não há afecção 
não poderia haver nem ser-no-mundo nem ser-com-o-outro." ${ }^{26} \mathrm{Na}$ medida em que o existencial da disposição é a condição de possibilidade para que a presença se dirija ao mundo e assim ao outro, dizemos que a disposição é o fundamento da estrutura ser-no-mundo e, consequentemente, do existencial do ser-com. Podemos ainda acrescentar que a disposição é o fundamento de todo e qualquer relacionar-se da presença com o mundo, ou seja, ela é a fonte de todos os humores, afetos, emoções etc. Dessa maneira ela é o fundamento ontológico-existencial de todas as afinações. Mas como a disposição constitui o ser-com? Do nosso ponto de vista a disposição fundamenta o ser-com como a afinação do amor. Por quê? Por ele ser caracterizado pela solicitude.

Da mesma forma que a afinação é o modo como onticamente conhecemos a disposição, entendemos que a solicitude é o modo como onticamente conhecemos o ser-com. Considerando-se que o amor é um modo de afinação da presença com a co-presença e que a solicitude do ser-com caracteriza a relação de abertura entre uma presença e outra, temos condições de afirmar que a solicitude é imprescindível para a constituição ontológico-existencial da afinação do amor, pois o afeto do amor é impensável sem a abertura da presença para o outro. Nesta perspectiva, a solicitude será o nosso esteio para refletirmos sobre a afinação e abertura do amor.

A caracterização do encontro com os outros também se orienta segundo a própria presença. [...] Os "outros" não significam todo o resto dos demais além de mim, do qual o eu se isolaria. Os outros, ao contrário, são aqueles dos quais, na maior parte das vezes, não se consegue propriamente diferenciar, são aqueles entre os quais também se está. ${ }^{27}$

Dito de outra forma, a presença é o outro de si mesma. Isto significa que a presença compreende o seu próprio ser, na medida em que compreende também o ser da outra presença e reciprocamente. Neste sentido, podemos indicar uma duplicidade no existencial do ser-com no que diz respeito a compreensão de ser da presença: ela compreende a si a partir da compreensão do outro, e compreende o outro mediante a compreensão de si. Temos aqui uma circularidade ontológica, da qual não temos como escapar, visto que a estrutura existencial da presença assim como a compreensão de ser elaboradas em Ser e tempo acontecem em uma circularidade. A presença, "o ente em que está em jogo seu próprio ser como ser-no-mundo possui uma estrutura 
de círculo ontológico." ${ }^{28}$ Por isto ela compreende o ser, a si e ao outro em uma circularidade ontológica. $\mathrm{Na}$ circularidade do ser-com, a presença se compreende como o ente que ela mesma é, ou seja, ela se reconhece como um si que coexiste com o outro ao mesmo tempo em que reconhece o outro também como um si que coexiste com ela e para quem ela é o outro. A presença "pode reconhecer outros como ela mesma no mundo e entrar em relação com eles porque seu próprio ser está aberto a ela como ser-com." 29 Dessa maneira, podemos dizer que o termo "com" responde pelo caráter de abertura da presença para a compreensão do ser do outro e de sua coexistência.

Em Ser e tempo quando a presença libera seu ser em direção aos outros, esta é denominada de co-presença e as outras presenças que coexistem e compartilham o mundo com a presença e a co-presença são denominadas de co-presentes. A presença libera seu ser em direção a co-presença porque é estruturada pela abertura para o outro que caracteriza o existencial do ser-com. Na medida em que é estruturada pelo ser-com, a presença está aberta a estarcom a co-presença, ou seja, ela se dirige para o encontro com a outra presença. Devemos lembrar que a co-presença, por sua vez, é também presença que libera seu ser em direção a outra presença (co-presença). A simultaneidade e reciprocidade da abertura e da liberação de ser entre presença e co-presença evidenciam mais uma duplicidade no existencial do ser-com: a liberação de ser da presença em direção a co-presença e reciprocamente. Daí podemos afirmar que o caráter de abertura do ser-com determina outra duplicidade concernente a circularidade ontológica do ser-com, qual seja, a compreensão de ser do outro e a liberação de ser em direção ao outro. Embora distintos os caracteres destas duplicidades são inseparáveis e constituem, via copertinência, a unidade da circularidade ontológica do ser-com. Melhor dizendo: a abertura do ser-com antecede e fundamenta a compreensão e a liberação de ser para o outro. Desta forma, a compreensão e a liberação de ser para o outro são cooriginárias e copertencentes a unidade de abertura da circularidade ontológica do ser-com. Qual a contribuição da circularidade ontológica do ser-com para a nossa reflexão sobre o amor como afinação? Ela fundamenta e determina a convivência cotidiana da presença, sem a qual não poderíamos falar de abertura e afinação do amor. A coexistência, originária da circularidade ontológica do ser-com, funda a convivência da presença, nela a presença é ser-com-para-o-outro e em virtude do outro. Por que na convivência o ser-com

29 KING, Magda. A Guide to Heidegger's Being and Time. New York: State University of New York, 2001; p. 75. 
pode compreender e liberar o ser para o outro? Porque o ser-com é solicitude, a abertura que antecede a compreensão e fundamenta a liberação de ser para o outro. O que nos permite correlacionar o ser-com a afinação do amor? O fato de que "é nos afetos (afinação) que o Dasein se descobre liberado e exposto ao ser." ${ }^{30}$ É no ser-com que a presença se abre para o outro, mas é na afinação do amor que a presença pode efetivar o encontro, o estar-com a co-presença através da compreensão e liberação de ser para o outro. Assim o ser-com é o existencial que estrutura a presença como abertura para o outro e o amor é a abertura da presença para o encontro, o estar-com o outro; desta forma o amor é afinação, uma modificação existencial da disposição que caracteriza a presença em sua relação com a co-presença. Neste sentido, o amor é a afinação fundamental para a convivência cotidiana da presença.

\section{A solicitude do ser-com e a abertura da afinação do amor}

"A abertura da co-presença dos outros, pertencente ao ser-com, significa: na compreensão do ser da presença já subsiste uma compreensão dos outros, porque seu ser é ser-com."31 A partir desta citação de Ser e tempo e daquela dos Seminários de Zollikon ${ }^{32}$ pretendemos correlacionar a abertura do ser-com à abertura da afinação do amor; porque a primeira afirma que a abertura da copresença implica na copertinência entre a compreensão de si e a compreensão do outro, e a segunda afirma que o amor, por similaridade a cura, copertence a compreensão de ser. Estas citações nos permitem inferir que na afinação do amor a presença se coloca em virtude do outro e se compreende a partir da compreensão de ser da co-presença. Com tal inferência não estamos justapondo, reduzindo ou transformando a abertura do ser-com em abertura da afinação do amor. A propósito nosso objetivo é mostrar que do existencial do ser-com é possível fundamentarmos o modo de afinação do amor e aprofundarmos nos estudos da filosofia heideggeriana. Conforme antecipamos do nosso ponto de vista a solicitude, a abertura do ser-com, é a condição de possibilidade para a constituição ontológico-existencial da afinação do amor, já que é notório que esta afinação carece da abertura ao outro para se fundamentar. Como se constitui a solicitude da presença?

Anteriormente afirmamos que o ser-com apresenta uma circularidade ontológica evidenciada pelo caráter de duplicidade referente a compreensão 
e a liberação de ser para o outro. Se o ser-com é o fundamento ontológicoexistencial da solicitude, consequentemente, esta também apresentará um caráter de duplicidade, qual seja, este da solicitude própria e da solicitude imprópria. No entanto, se partimos do pressuposto que a abertura do sercom, a solicitude, funda a abertura da afinação do amor, devemos igualmente pressupor que a duplicidade da solicitude fundamenta uma duplicidade na afinação do amor. Qual será o caráter desta duplicidade? Como interagem as duplicidades do ser-com e da solicitude com esta da afinação do amor? O que estas duplicidades significam para a constituição da presença enquanto serno-mundo?

O ser-com se exprime através da solicitude. Esta estrutura existencial fundamental admite evidentemente um grande número de variações, tanto positivas quanto negativas. Sobre a versão negativa, há numerosas formas de indiferença, da "não-assistência a pessoas em perigo" que fazem parte do funcionamento efetivo da sociedade. Sobre a versão positiva Heidegger menciona duas modalidades fundamentais: no primeiro caso, eu me substituo ao outro para procurar para ele isto que ele mesmo não pode procurar. [...] Ao lado desta primeira possibilidade (desencarregar o outro de seus "cuidados" tomando-os para si) Heidegger visa uma outra possibilidade que concerne diretamente a existência do outro. Ela consiste em tornar o outro suficientemente livre e autônomo para que ele possa assumir seus cuidados. ${ }^{33}$

Quando a presença se coloca no lugar do outro, substituindo-o no cuidado consigo mesmo dizemos que a solicitude é imprópria e quando a presença abre para o outro a possibilidade de cuidar-se de si dizemos que a solicitude é própria. Podemos ir além desta descrição de Ser e tempo e acrescentar que a solicitude própria e imprópria fundamentam a duplicidade da afinação do amor como abertura e fechamento. Que diferença podemos estabelecer entre os pares próprio/impróprio e abertura/fechamento? A diferença consiste em que o primeiro par refere-se a modos de ser da presença e o segundo ao caráter dos existenciais. Por exemplo: a solicitude, enquanto abertura, é um caráter do existencial do ser-com. Mas a solicitude é própria quando exprime o ser-com de modo genuíno e libertador e é imprópria quando exprime o ser-com de modo nivelador e dominador. Na versão positiva da solicitude, a convivência da presença é regida pela solicitude própria e imprópria. Por outro lado, podemos falar de abertura e fechamento da afinação do amor para nos referirmos aos caracteres que constituem ontologicamente esta afinação do existencial da disposição porque como modalidade deste existencial a afinação do amor 
conserva os mesmos caracteres. Então somente a partir do caráter de abertura ou de fechamento podemos falar em modos de ser da afinação do amor. Isto significa que o caráter de abertura ou de fechamento determina modos de ser próprio ou impróprio. Qual a relevância das duplicidades do ser-com e da solicitude para a constituição da afinação do amor?

A duplicidade do ser-com, caracterizada pela circularidade ontológica da compreensão e da liberação de ser para o outro, e a duplicidade da solicitude própria e imprópria fundam a duplicidade da afinação do amor (abertura e fechamento), na medida em que convergem a afinação do amor para a compreensão, liberação e solicitude com o outro. Desta convergência é possível afirmar que na afinação do amor a presença pode abrir-se para o outro e compreender-se a si, assumindo o seu próprio poder-ser ao mesmo tempo em que libera o outro para compreender-se, libertando-o para assumir a responsabilidade de ser si-mesmo. No caráter de abertura da afinação do amor a presença e a co-presença são livres para ser e assumir o que elas têm de ser. De outro lado, da convergência destas duplicidades é possível também afirmar que na afinação do amor a presença pode fechar-se para o outro obnubilando a si e a ele a compreensão e a liberação de ser que diz respeito a cada um. Nesta obnubilação de compreensão e liberação de ser tanto a presença quanto a co-presença se eximem da responsabilidade de assumir o seu poder-ser. Em consonância com o pensamento heideggeriano em Ser e tempo e além dele, diremos que o caráter de abertura da afinação do amor funda o modo próprio de ser do amor, ao passo que o caráter de fechamento funda o modo impróprio de ser do amor. Enquanto na solicitude imprópria a presença se coloca no lugar do outro para cuidar daquilo que lhe concerne, desencarregando e desincumbindo-o de assumir o cuidado consigo mesmo, substituindo-lhe, portanto neste cuidado; no fechamento da afinação do amor a presença se compreende no modo de ser que a co-presença lhe confere, assumindo para si um modo de ser que não é seu, identificando-se com ele e fechando-se para suas próprias possibilidades de ser. Qual a diferença entre o modo da solicitude imprópria e este do fechamento da afinação do amor? A diferença está em que na solicitude imprópria a presença substitui o outro no cuidado consigo e no fechamento da afinação do amor a presença assume como sua a compreensão de ser que o outro tem dela, afastando-se e perdendo-se de si mesma. Apesar desta diferença que apontamos, podemos dizer que a solicitude imprópria e o fechamento da afinação do amor desembocam no mesmo lugar, qual seja, no retraimento da liberação de ser. Desta maneira torna-se evidente a copertinência e co-originariedade da solicitude imprópria e do fechamento da afinação do amor na circularidade ontológica do ser-com. Esta evidência 
esclarece ainda que a solicitude imprópria e o fechamento da afinação do amor nivelam o modo de ser da co-presença ao da presença. Concomitantemente, na solicitude própria a presença libera o outro para cuidar-se de si, para ser autônomo e livre. Já na abertura da afinação do amor, a presença libera o outro para assumir o seu próprio ser, tornando-se transparente para si e para a copresença, ao mesmo tempo em que deixa que a co-presença seja isto que ela tem de ser. Com isto a presença libera a co-presença para o seu poder-ser, para compreender-se a si mesma e, reciprocamente, se compreende como ser livre e transparente para o seu próprio poder-ser. A solicitude própria e a abertura da afinação do amor copertencem e são co-originárias na circularidade ontológica do ser-com, a saber, a compreensão e a liberação de ser da presença e da copresença.

\section{O estar-só do ser-com e a afinação da solidão}

"O ser-com determina existencialmente a presença, mesmo quando um outro não é, de fato, dado ou percebido. Mesmo o estar-só da presença é sercom no mundo. Somente num ser-com e para um ser-com é que o outro pode faltar. O estar-só é um modo deficiente de ser-com, e sua possibilidade é a prova disso." ${ }^{34}$ Mas em que sentido a presença pode estar-só, se existencialmente ela é ser-em, ser-junto ao mundo e ser-com a co-presença? Por que o estarsó é um modo deficiente do ser-com? Qual a afinação correspondente a este modo de ser da presença? Qual a relação entre o estar-só e a afinação do amor? A deficiência do estar-só não se refere a um fator negativo da estrutura existencial do ser-no-mundo, ao contrário, o estar-só denuncia a falta da copresença para o ser-no-mundo. Esta falta denunciadora, em vez de ocultar ou enfraquecer o ser-com, o desmascara e o fortalece, pois evidencia que se de fato a co-presença pode faltar ao ser-no-mundo é "porque a presença, enquanto ser-com, permite o encontro de muitos em seu mundo." 35

Dizemos que quando a presença se sente só ela está solitária, por isto podemos referir o termo "solidão" ao estar-só do ser-com. No entanto, a solidão não é um modo deficiente da presença, antes ela é uma afinação da presença com o outro no modo do estar-só. Mas se o estar-só é um modo deficiente do ser-com por que negamos que a solidão seja um modo deficiente da presença? Porque o estar-só, por um lado, é um modo do ser-com e, por outro, é um caráter da afinação que expõe a presença no modo de ser sozinha. Fazemos esta 
afirmação, respaldados no fato de que na analítica existencial a presença está sempre em uma afinação, quer dizer, ela está sempre afinada a uma situação "a partir do mundo compartilhado nas ocupações do mundo circundante."36 Esta consideração implica em que a presença, enquanto estruturada pelo modo deficiente do ser-com, está na afinação da solidão. Desta maneira, podemos então afirmar que o existencial do ser-com fundamenta a afinação da solidão. Entretanto, anteriormente afirmamos que o existencial do ser-com fundamenta a afinação do amor. Há uma contradição latente nestas afirmações? Não, nosso intuito com tais inferências é mostrar que o existencial do ser-com, através do modo de ser do estar-com fundamenta a afinação do amor, e mediante o modo de ser do estar-só fundamenta a afinação da solidão. Conforme já indicamos, o ser-com é caracterizado por uma circularidade ontológica estrutural, que caracteriza a duplicidade da solicitude e da afinação do amor. Ora, se a solidão, assim como o amor, é uma afinação fundamentada pelo ser-com, então ela também será caracterizada por uma duplicidade. Como se constitui a duplicidade da solidão? Vimos que um par desta duplicidade é o estar-só que marca a falta da co-presença. Qual será o outro par? O estar-só que singulariza a presença. "O que é esta solidão, na qual o homem sempre e a cada vez vem a ser como único? O que é isto - a singularização?"37

A duplicidade que caracteriza a solidão consiste, por um lado, no fato de a presença sentir-se só e abandonada pela co-presença encontrando-se em uma situação de afastamento de si e, por outro, no fato de a presença sentir-se só e abandonada a si-mesma, encontrando-se em uma situação de proximidade consigo mesma. A diferença destes modos de estar-só, característicos da afinação da solidão, está em que no primeiro caso o outro se faz presença (Dasein) no modo da falta, ou seja, a co-presença faltante determina o modo de ser da presença como perda e vazio de si. Este modo de afinação da solidão concerne ao abandono e a dispersão do ser da presença ao outro, pois, enquanto afinação, a solidão se fundamenta no existencial da disposição e esta "é o modo de ser existencial em que a presença permanentemente se abandona ao 'mundo' e por ele se deixa tocar de maneira a se esquivar de si mesma." ${ }^{38} \mathrm{O}$ outro modo de estar-só da solidão desmascara a presença para si mesma singularizando-a. No modo da falta, a presença conta com a copresença para preencher o seu vazio de ser, neste modo a presença confia que a co-presença pode decidir-se sobre o poder-ser que ela mesma tem de ser, 
assim a presença se dispersa na espera de decisão da co-presença, afastandose de si mesma. Já no modo da singularização a presença se recusa a prenderse na falta do outro e na espera de decisão da co-presença e assume o seu poder-ser próprio tornando-se singular e única. Neste caso temos "um ficar só no qual cada um se encontra a partir de si mesmo como um singular diante da totalidade." 39 Portanto a solidão, no modo da singularização, em vez de exibir a perda e distanciamento da presença de si mesma, diz respeito a proximidade e conquista do poder-ser que ela mesma é. Neste sentido, a solidão singulariza a presença porque possibilita que ela seja transparente para si ao realizar um modo próprio de ser que a caracteriza como única diante da co-presença no mundo compartilhado. Como podemos correlacionar a afinação da solidão à afinação do amor? Elas são copertencentes e co-originárias na circularidade ontológica do ser-com, na qual a presença compreende e libera ser para o outro. "O ser para o outro não é apenas uma remissão ontológica irredutível e autônoma. Ele já está sendo, enquanto ser-com, o ser da presença." ${ }^{40}$ Quer dizer, o caráter de abertura para o outro que exprime o ser-com como solicitude fundamenta a afinação da solidão e a afinação do amor. A copertinência e co-originariedade da solicitude, afinação da solidão e afinação do amor se constitui na circularidade ontológica do ser-com.

\section{A ressonância das afinações do amor e da liberdade}

Em Nietzsche I, Heidegger afirma que "o amor precisa ser entendido como vontade, como a vontade que quer que o amado seja, em sua essência, o que ele é." ${ }^{41}$ Vimos, anteriormente, que para Nietzsche vontade é afeto, então a frase "o amor entendido como vontade" pode ser lida da seguinte maneira: o amor entendido como afeto. Em Ser e tempo, afeto corresponde a disposição e se concretiza como afinação. Então, se o amor é afeto, logo, ele é afinação: uma modificação do existencial da disposição. Esta argumentação comprova a tese principal de nossa reflexão, qual seja, o amor é uma afinação fundamental para a convivência da presença. Na medida em que o amor é uma afinação ele é também um "comportamento", ou seja, um encontro da abertura da presença com a abertura da co-presença, um portar-se conjunta e abertamente, visto que "na disposição, o comportamento encontra a cada 
vez um começo." ${ }^{42}$ A abertura recíproca da presença e da co-presença é a condição necessária e originária para o comportamento, para o encontro e o retorno do ser-no-mundo a suas possibilidades de ser. Na disposição, retorno e começo constituem o momento inaugural e fundador dos modos de ser da presença. "Este poder-voltar-a-começar também poderia denominar-se, simplesmente, liberdade." ${ }^{43}$ Entendida como deixar-ser o outro naquilo que ele é, a liberdade é o fundamento para o desvelamento do modo próprio de ser da presença. Em Sobre a essência da verdade, a liberdade enquanto deixar-ser o ente é considerada uma "disposição de humor ou uma disposição afetiva [afinação] na qual a presença já está abandonada sem pressentir. Enquanto tal, a liberdade penetra e precede todo o comportamento aberto que nela se desvela." ${ }^{44}$ Paralelamente a interpretação de Heidegger sobre o amor fati podemos dizer que na afinação do amor a presença libera ser para o outro, ou seja, deixa a co-presença ser isto que ela é. Assim a afinação do amor e a afinação da liberdade são igualmente co-originárias e copertencentes ao comportamento aberto da presença. Pois, "toda relação de abertura, pela qual se instaura a abertura para algo, é um comportamento. [...] A liberdade em face do que se revela no seio do aberto deixa que cada ente seja o ente que é. (Desta maneira) A liberdade é o abandono ao desvelamento do ente como tal. ${ }^{.45} \mathrm{Na}$ medida em que na afinação do amor a presença e a co-presença podem ser o que são, dizemos que a afinação do amor copertence a afinação da liberdade. Porque a afinação da liberdade articula as aberturas para ser da presença e da co-presença e deixa que elas sejam o ente que são, podemos declarar que a afinação da liberdade é a condição de possibilidade para a afinação do amor. Isto significa que a afinação da liberdade precede e penetra a afinação do amor. Melhor: a articulação das aberturas para ser da presença e co-presença na afinação da liberdade possibilita o encontro, o comportamento, das aberturas da compreensão e liberação de ser para o outro na afinação do amor. Tal articulação torna evidente que na afinação do amor "a liberdade é a mais alta necessidade." ${ }^{46}$ Devido a articulação entre as aberturas para ser da presença e co-presença e das aberturas para a compreensão e liberação de ser para o outro, que permitem que a presença e a co-presença assumam o poder-ser

42 FIGAL, Günter. Martin Heidegger: fenomenologia da liberdade; p. 149.

43 SAFRANSKI, Rüdiger. Heidegger e el comenzar. Madrid: Ediciones Pensamiento, 2006; p. 30.

44 Cf. HEIDEGGER, Martin. Sobre a essência da verdade. In: Heidegger: conferências e escritos filosóficos. São Paulo: Abril Cultural, 1979. (Os Pensadores); p140.

45 Idem. Ibidem; p. 136, 138.

46 Idem. Hölderlin und das Wesen der Dichtung. In: Erläuterungen zu Hölderlins Dichtung. Frankfurt, Vittorio Klostermann, 1951; p. 42. 
que elas têm de ser, pensamos que a afinação do amor se funda na afinação da liberdade como deixar-ser e que esta ressoa naquela. Entendemos assim porque no modo próprio da afinação do amor a presença deixa que a co-presença seja isto que ela tem de ser, liberando a si e a co-presença para a singularização e reciprocamente. Desta forma, constatamos a co-originariedade e a copertença entre a afinação da liberdade e a afinação do amor.

A convivência recíproca daqueles que se empenham na mesma coisa alimenta-se, muitas vezes, somente de desconfiança. Inversamente, o empenhar-se em comum pela mesma coisa determina-se a partir da presença apreendida, cada vez, propriamente. É essa ligação própria que possibilita a justa isenção, que libera o outro em sua liberdade para si mesmo. ${ }^{47}$

O modo da desconfiança que rege muitas vezes a convivência recíproca da presença exprime o caráter de fechamento da afinação da liberdade e, concomitantemente, o caráter de fechamento da afinação do amor. Estes caracteres determinam a presença em modos impróprios de ser. Do fechamento da presença para o acolhimento da abertura de ser da co-presença e recusa da presença em deixar que a co-presença seja ela mesma, temos o modo impróprio da afinação da liberdade. E do fechamento da presença para o acolhimento da abertura e compreensão para o outro ou na recusa da presença em liberar o ser para o outro, concedendo a co-presença que assuma o ser que ela mesma é, temos o modo impróprio da afinação do amor. Da mesma forma que a afinação do amor e a afinação da liberdade, os caracteres de fechamento e modos impróprios destas afinações são co-originárias e copertencentes.

Podemos ainda acrescentar que no modo impróprio da afinação do amor parece que a presença toma a co-presença como se ela fosse um simplesmente dado, apesar de que "não se pode de forma alguma compreender o que é propriamente si-mesmo como algo simplesmente dado." ${ }^{48} \mathrm{Na}$ impropriedade, a presença desencarrega a co-presença de ser o que ela é (solicitude imprópria) ao mesmo tempo em que determina o modo de ser que ela deve assumir como seu [afinação imprópria do amor]. Nesta medida dizemos que há um encontro do caráter de fechamento da presença e da co-presença para as possibilidades próprias de ser de cada uma. Por isto afirmamos que na afinação imprópria do amor há uma afinação imprópria da liberdade, visto que na afinação imprópria do amor a co-presença coexiste com o fechamento da presença para a liberação do poder-ser que lhe é próprio. Portanto, no fechamento e 
impropriedade das afinações da liberdade e do amor a presença e a co-presença se exprimem através do modo da dissimulação e do desvio de si-mesma, o qual nivela e massifica a convivência cotidiana, pois aí cada um se exime da responsabilidade de ser si-mesmo e joga para o outro a necessidade de assumir a liberdade de ser.

Encarregar-se de uma 'coisa' ou de uma 'pessoa' em sua essência significa: ama-la, quere-la. Este querer significa, quando pensado mais originariamente: gratificar a essência. Tal querer é a essência propriamente dita do poder, o qual não é apenas capaz de produzir isto ou aquilo, mas é capaz de deixar que algo desdobre seu ser em sua pro-veniência, isto significa, que é capaz de deixar-ser. ${ }^{49}$

Encarregar-se de alguém não significa ser em seu lugar, assumir os seus cuidados ou conservar este alguém para si, antes significa doação de ser, ou seja, gratuidade em desdobramentos de liberação de possibilidades de ser e generosidade para abandonar-se ao desvelamento do ente e para conceder a proveniência do ser outro de si mesmo. Isto significa empenhar-se conjuntamente para que cada um seja livre para ser o que propriamente se é. O empenhar-se da presença em compreender e assumir o poder-ser que ela é e em compreender e liberar a co-presença para assumir o poder-ser que ela é, expressa o caráter de abertura da presença para o outro como deixar-ser a co-presença. Neste tipo de empenho fica em suspenso os modos impróprios da afinação do amor, melhor, neste empenho está suspenso o controle sobre o modo de ser do outro, a cobrança que o outro seja deste ou daquele modo e a barganha ou o comércio de possibilidades de ser. Com esta suspensão temos o encarregar-se de alguém no modo do empenho livre para ser o que se é, ou seja, temos o modo próprio da afinação do amor. Consideramos que este modo de afinação que cuida, compreende e libera o outro para ser si-mesmo seja necessário e fundamental para a convivência livre e recíproca da presença e da co-presença. Nesta perspectiva, pensamos que, em Heidegger, a afinação do amor requer a co-originariedade e a copertença com a afinação da liberdade. Portanto, a liberdade enquanto deixar-ser o que se é, "ressoa necessariamente em todo amor." 50

49 Idem. Sobre o "humanismo". In: Heidegger: conferências e escritos filosóficos. São Paulo: Abril Cultural, 1979. (Os Pensadores); p. 150-1.

50 Idem. Nietzsche I; p. 366. 


\section{Referências bibliográficas}

AGAMBEN, Giorgio; PIAZZA, Valeria. L'ombre de l'amour: le concept d'amour chez Heidegger. Paris: Payot \& Rivages, 2003.

CABESTAN, Philippe; DASTUR, Françoise; Ecole Française de Daseinanalyse (org.). Lectures d'Être et temps de Martin Heidegger: Quatre-vingts ans après. Argenteuil: Le Cercle Herméneutique, 2008.

FIGAL, Günter. Martin Heidegger: fenomenologia da liberdade. Rio de Janeiro: Forense, 2005.

GREISCH, Jean. Ontologie et temporalité: esquisse d'une interprétation intégrale de Sein und Zeit. Paris: PUF, 1994.

HEIDEGGER, Martin. Ser e tempo. Petrópolis: Vozes, 2006.

. Seminários de Zollikon. Petrópolis: Vozes, 2001.

. Conceitos fundamentais de metafisica: mundo, finitude, solidão. Rio de Janeiro: Forense, 2003. . Nietzsche I. Rio de Janeiro: Forense, 2007. - Question II. Paris: Gallimard, 1968.

. Heidegger: conferências e escritos filosóficos. São Paulo: Abril Cultural, 1979. (Os Pensadores).

Klostermann, 1951. . Erläuterungen zu Hölderlins Dichtung. Frankfurt, Vittorio

KING, Magda. A Guide to Heidegger's Being and Time. New York: State University of New York, 2001.

SAFRANSKI, Rüdiger. Heidegger e el comenzar. Madrid: Ediciones Pensamiento, 2006. 